\title{
Cleogonus insulcatus Fiedler, 1954 (Coleoptera: Curculionidae): first report in Brazil and a new host plant record, Handroanthus impetiginosus (Mart. ex DC.) Mattos
}

\author{
Marcelo T. Castro ${ }^{1 \pm=(\infty)}$, Sandro C. L. Montalvão ${ }^{2}$, Germano H. Rosado-Neto ${ }^{3}$, Rose G. \\ Monnerat ${ }^{2}{ }^{\circledR}$ \\ ${ }^{1}$ Centro Universitário ICESP de Brasília, Distrito Federal, Brazil. ${ }^{2}$ Embrapa Recursos Genéticos e Biotecnologia, Distrito Federal, \\ Brazil. ${ }^{3}$ Universidade Federal do Paraná, Paraná, Brazil.
}

䒠='Corresponding author: marceloengflorestal@gmail.com

Edited by: Flavia R. Fernandes

Received: April 11, 2020. Accepted: August 03, 2020. Published: September 10, 2020.

\begin{abstract}
The purple trumpet tree [Handroanthus impetiginosus (Mart. Ex DC.) Mattos - Bignoniaceae] is one of the most prominent tree species in the Brazilian Federal District, with more than 150 trees in the Plano Piloto region of Brasília. In March 2017, weevils (Coleoptera) were observed in ripe fruits of purple trumpet trees feeding on already dried seeds. The objective of this paper is to report and describe the main damage to seeds and pods of $\mathrm{H}$. impetiginosus in Brasília, Brazil, caused by this beetle. The insect was identified as Cleogonus insulcatus Fiedler, 1954 (Coleoptera: Curculionidae). Of the 126 fruits analyzed, 104 exhibited predation by $C$. insulcatus (82.5\%) and 377 larvae were collected inside the pods feeding on the seeds. This is the first report of $C$. insulcatus in Brazil and the first record of damage to $H$. impetiginosus pods and seeds caused by this insect.
\end{abstract}

Keywords: Fruit Damage, Forest Entomology, Weevil.

The urban afforestation of Brasília is extremely rich and composed of hundreds of ornamental and fruit species (Silva Junior \& Lima 2010). Among the trees, trumpet tree attracts attention due to its exuberant flowering. The purple trumpet tree, Handroanthus impetiginosus (Mart. ex DC.) Mattos = Tabebuia impetiginosa Mart. ex DC. (Bignoniaceae), is one of the most prominent tree species in the Federal District, with more than 150 trees in the Plano Piloto region of Brasilia (Kurihara et al. 2005; Silva Junior \& Lima 2010).

Several insects of the orders Lepidoptera, Coleoptera, Hymenoptera, and Hemiptera have been found associated with purple trumpet tree. Among the damage, the psyllid Trioza tabebuiae Buckhardt \& Queiroz, 2001 (Hemiptera: Psylloidea) has been reported to cause leaf curl on Tabebuia alba (Cham.) Sandwith, Tabebuia chrysotricha Standl, and Tabebuia heptaphylla (Vell.) Toledo in Paraná, Brazil (Santana et al. 2005; Queiroz et al. 2009). The beetle Dorynota pugionata (Germar, 1824) (Coleoptera: Chrysomelidae) was observed damaging T. alba and T. chrysotricha (Buzzi \& Cruz 1991). A review of these insects can be found in Santana et al. (2005).

In March 2017, weevils (Coleoptera) were observed in ripe fruits of purple trumpet tree feeding on already dried seeds (Fig. 1). To investigate this insect more thoroughly, this paper reports and describes the main damage caused by this insect to $H$. impetiginosus seeds and pods in Federal District, Brazil.

We collected 126 physiologically green fruits of purple trumpet tree still suspended on the trees during August, September, and October 2017 (42 fruits each month). For this, 20 trees were randomly selected for the collections. The material was taken to the Laboratory of Plant Sciences of the Centro Universitário ICESP in Brasília, where they were weighed, and the number of external holes caused by insects in the pods counted. The pods were opened with a stylus and the total number of larvae inside the fruits were counted. In addition, aspects related to fruit predation were observed, such as the most attacked portion of the fruit (upper or lower) and the presence of other arthropods.
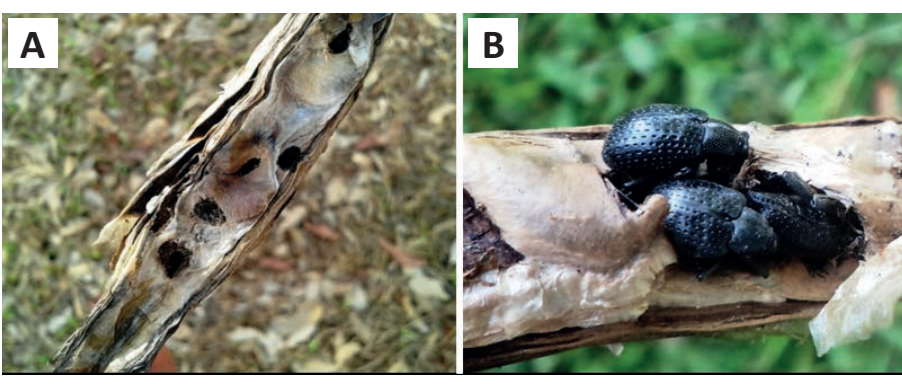

Figure 1. Damage observed on purple trumpet tree seeds in Brasília, Federal Distric. A - Seeds damaged by the beetles. B - Adults of Cleogonus insulcatus Fiedler, 1954 (Coleoptera: Curculionidae) preying on seeds.

To confirm the genus of the insect, some larvae were separated and placed to pupate, following the methodology proposed by Santos et al. (2001). The adults obtained were killed and stored in bottles containing $70 \%$ alcohol and compared with the insects obtained in March 2017. Adult specimens are deposited in the Entomological Collection Pe. Jesus Santiago Moure - DZUP (Coleoptera Collection), Universidade Federal do Paraná, Curitiba, PR under reference number 0143/2018-RN.

Beetles were identified as Cleogonus insulcatus Fiedler, 1954 (Coleoptera: Curculionidae). Of the 126 fruits analyzed, 104 had been preyed on by the insect $(82.5 \%)$, and 377 larvae were collected inside the pods feeding on seeds, in which 120 were obtained in August, 115 in September, and 142 in October, indicating that number of larvae remained similar in three months studied. During evaluation period, no adults or other insects associated with pods were found, which indicates that in studied region the attack on purple trumpet tree fruits is prevalent by this species of Curculionidae. Up to 14 larvae were found in a single fruit, with an average of three per sample, including non-infested ones. Link \& Costa (1988) found up to 13 larvae of Rhyssomatus sp. (Coleoptera: Curculionidae) in each yellow trumpet tree pod in Santa Maria, RS, and more than $95 \%$ of the fruits were 
infested by this beetle.

The damage caused by this insect was recorded mainly in the lower pods ( $86 \%$ of the attacked fruits), indicated that the attack occurs mainly from the bottom up (Fig. 2A). As the damage increased, a large amount of excrement was produced and the seeds were completely consumed, with damaged and blackened pods. In intense attacks, all seeds were preyed on and useless for planting. The larvae is whitish, with typical morphological features of Curculionidae family (Fig. 2B).

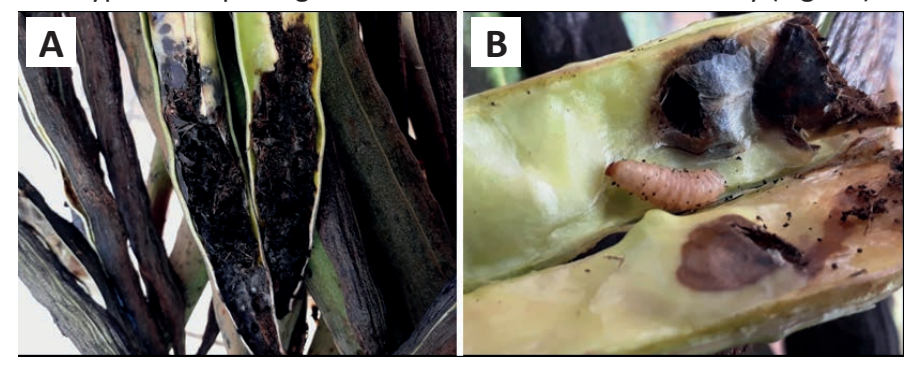

Figure 2. Attack of Cleogonus insulcatus Fiedler, 1954 on green pods of purple trumpet tree. A - Damaged pods with seeds preyed on by larvae. B - Detail of the larva on the seeds.

The holes caused by $C$. insulcatus were an average size of $2 \mathrm{~mm}$ and could have been used for entry into the pods or made by the female for oviposition, as observed by Link \& Costa (1988). The presence of gum and droppings is easily seen near the holes made by the weevils. Up to eight holes per fruit were found, with an average of two in all samples. The observation of holes is an important sign of insect attack on fruits, as demonstrated by Castro et al. (2018a) to detect the presence of Hypsipyla grandella (Zeller, 1848) (Lepidoptera: Pyralidae) in cedar, Cedrela fissilis Vell. (Meliaceae), and mahogany Swietenia macrophylla King (Meliaceae) (Castro et al. 2018b).

Species of Cleogonus Schönherr, 1825 have been reported to damage pods from plants of Leguminosae family and are believed to be specialized and obligatory predators of seeds, especially legumes (Janzen et al. 1976; Polak \& Brown 1995). Cleogonus weevils can destroy up to $90 \%$ of Andira inermis (Leguminosae) seeds produced by a tree (Janzen et al. 1976). The literature does not contain much information about $C$. insulcatus. Prena \& Whitehead (2012) reported that the species is restricted to Argentina and that its probable hosts are unknown. Therefore, this is the first report of $C$. insulcatus in Brazil and the first record of this beetle damaging pods and seeds of $H$. impetiginosus.

\section{Author's Contributions}

MTC: Performed the material collection and analysis; wrote the manuscript. SCLM: Performed the material collection and analysis; wrote the manuscript. GHRN: Identified the weevil species and contributed to the interpretation of the results; wrote the manuscript. RGM: Contributed to the interpretation of the results.

\section{References}

Buzzi, Z. J.; Cruz, M. S. (1991) Ciclo evolutivo de Dorynota pugionata (Coleoptera, Chrysomelidae) em Tabebuia alba e T. chrysotricha (Bignoniaceae). Anais da Sociedade Entomológica do Brasil, 20: 149-154.

Castro, M. T.; Montalvão, S. C. L.; Monnerat, R. G. (2018a) Ocorrência de Hypsipyla grandella Zeller em Frutos e Sementes de Cedro (Cedrela fissilis Vell.) em Brasília. Floresta e Ambiente, 25(1): 1-4. doi: 10.1590/2179-8087.133015

Castro, M. T.; Montalvão, S. C. L.; Monnerat, R. G. (2018b) Damage in fruits of mahogany caused by Hypsipyla grandella (Zeller) (Lepidoptera: Pyralidae) in Brasília, Brazil. EntomoBrasilis, 11(1): 09-12. doi: 10.12741/ebrasilis.v11i1.690

Janzen, D. H.; Miller, G. A.; Hackforth-Jones, J.; Pond, C. M.; Hooper, K.; Janos, D. P. (1976) Two Costa Rica bat-generated seed shadows of Andira inermis (Leguminosae). Ecology, 57(5): 1068-1075. doi: $10.2307 / 1941072$
Kurihara, D. L.; Imaña-Encinas, J.; Paula, J. E. (2005) Levantamento da Arborização do Campus da Universidade de Brasilia. Cerne, 11(2): 127-136.

Link, D.; Costa, E. C. (1988) Nível de infestação de larvas de Rhyssomatus sp. (Coleoptera: Curculionidae) em síliquas de ipê-amarelo, Tabebuia chrysotricha (Bignoniaceae). Anais do VI Congresso Florestal Estadual, Nova Prata, Rio Grande do Sul, p. 607-612.

Polak, M.; Brown, W. D. (1995) Mating tactics and courtship behavior in Cleogonus rubetra (Fabricius) (Coleoptera: Curculionidae). Journal of Insect Behavior, 8: 453-463. doi: 10.1007/BF01995319

Prena, J.; Whitehead, D. R. (2012) A taxonomic revision of the Neotropical weevil genus Cleogonus Schnherr (Curculionidae, Molytinae). Deutsche Entomologische Zeitschrift, 59(1): 55-79. doi: 10.1002/mmnd.201200004

Queiroz, D. L.; Burckhardt, D.; Andrade, D. P. (2009) Psilídeos no Brasil 5: Trioza tabebuiae em ipês. Colombo, PR: Embrapa Florestas (Comunicado Técnico). 5p.

Santana, D. L. Q.; Auer, C. G.; Rocha, A. L. J. L.; Marques, E. (2005) Insetos associados ao enrolamento foliar de Tabebuia spp. em viveiros e na arborização urbana de Curitiba. Boletim de Pesquisa Florestal, 50: 117-126.

Santos, G. P.; Zanuncio, T. V.; Freitas, M. F.; Alves, J. B.; Zanuncio, J. C. (2001) Danos causados por Rhyssomatus sp. (Coleoptera; Curculionidae), Triaspis sp. (Hymenoptera; Braconidae) e Lepidoptera (Pyralidae) em sementes de angico vermelho Piptadenia peregrina (Leguminosae). Revista Ceres, 48(279): 539549.

Silva Júnior, M. C.; Lima, R. M. C. (2010) 100 árvores urbanas - Brasília: guia de campo. Brasília: Ed. Rede de Sementes do Cerrado, 292 p. 